\title{
Kinetics of the Attachment of \\ Intrinsic Factor-Bound Cobamides to Ileal Receptors
}

\author{
V. I. Mathan, Bernard M. Babior, and Robert M. Donaldson, Jr. \\ From the Department of Medicine, Boston University School of Medicine, \\ Boston, Massachusetts 02118, and the Department of Medicine, Tufts-New \\ England Medical Center Hospital, Boston, Massachusetts 02111
}

A в S T R A C T To determine whether the molecular configuration of vitamin $\mathrm{B}_{12}$ influences the attachment of intrinsic factor-vitamin $\mathrm{B}_{12}$ complex to ileal microvillous membrane receptor sites, we have examined the kinetics of uptake of intrinsic factor-bound cyanocobalamin by brush borders and microvillous membranes isolated from guinea pig ileum, and have compared this uptake with that of intrinsic factor alone and with that of intrinsic factor complexed with various analogs of cyanocobalamin.

We first studied the kinetics of binding of cyanocobalamin and other cobamides to human gastric intrinsic factor. The binding of cyanocobalamin showed saturation kinetics and, at relatively high concentrations of cyanocobalamin, a Scatchard plot of binding was linear. The dissociation constant for the intrinsic factor-cyanocobalamin complex was $0.066 \mathrm{nM}$. When the binding of various vitamin $B_{12}$ analogs to intrinsic factor was determined by competition experiments, the analogs could be separated into two categories: those with affinities similar to that of cyanocobalamin and those with affinities much lower than that of cyanocobalamin. The affinity of cyanocobalamin for intrinsic factor was not altered by various substitutions at the $-\mathrm{CN}$ position, while removal of a single amido group on the corrin ring or substitution of the dimethylbenzimidazole base greatly reduced affinity. Removal of the base totally abolished binding. These findings, confirming those reported by others, are consistent with the concept that the cyanocobalamin molecule fits into a "pocket" in the

Dr. Mathan's current address is Wellcome Research Unit, Christian Medical College Hospital, Vellore-4, Tamil Nadu, India. Dr. Babior is the recipient of a Research Career Development Award from the National Institute of $\mathrm{Ar}$ thritis and Metabolic Diseases. Dr. Donaldson's current address is Veterans Administration Hospital, West Haven, Connecticut 06516.

Received for publication 3 July 1973 and in revised form 28 February 1974. intrinsic factor molecule, with the nucleotide base facing inward and the $-\mathrm{CN}$ side of the planar corrin ring facing outward.

We then investigated the attachment of intrinsic factor-bound cyanocobalamin to ileal receptor. Attachment to microvillous membranes showed saturation kinetics with a dissociation constant of $0.25 \mathrm{nM}$. Attachment was rapid and was $70 \%$ complete within 5 $\min$; the second-order rate constant for attachment was $1.3 \times 10^{6} \mathrm{M}^{-1} \mathrm{~s}^{-1}$. The half-time for dissociation of intrinsic factor-bound cyanocobalamin from the ileal receptor was approximately $35 \mathrm{~min}$. Free intrinsic factor inhibited the attachment of intrinsic factor-bound cyanocobalamin, but the rate of attachment of free intrinsic factor was slower than that of intrinsic factor bound to cyanocobalamin. When intrinsic factor was complexed with various analogs of cyanocobalamin, the affinities of these complexes for ileal microvillous membranes were similar to that of intrinsic factor-bound cyanocobalamin. These findings suggest that the molecular configuration of vitamin $\mathrm{B}_{12}$ is not a major determinant in the interaction between intrinsic factor-bound vitamin $\mathrm{B}_{12}$ and its ileal receptor site.

\section{INTRODUCTION}

Intrinsic factor (IF) ${ }^{1}$ binds vitamin $B_{12}$ in a macromolecular complex $\left(\mathrm{IFB}_{12}\right)$ and promotes uptake of the vitamin by small bowel mucosa (1). We previously showed that $\mathrm{IFB}_{12}$ attaches to specific receptor sites on microvillous membranes isolated from the distal half, but not the proximal half, of hamster small intestine

\footnotetext{
${ }^{1}$ Abbreviations used in this paper: (Ade) $\mathrm{CN}-\mathrm{Cba}, \alpha-$ (adenyl) cobamide cyanide; AdoCbl, adenosylcobalamin (coenzyme $\mathrm{B}_{12}$ ); CN-Cbl, cyanocobalamin; $\mathrm{CN}-\mathrm{Cbl}(\mathrm{OH})^{\mathbf{e}}$, $\alpha$-(5,6-dimethylbenzimidazole)-cobamic acid a,b,c,d,g-pentaamide cyanide; ( $\mathrm{CN}, \mathrm{OH}) \mathrm{Cbi}$, cyanoaquocobinamide; IF, intrinsic factor; KRB, Krebs-Ringer bicarbonate; MeCb1, methyl cobalamin; $\mathrm{OH}-\mathrm{Cbl}$, hydroxocobalamin.
} 
(2). Although hamster IF promotes vitamin $B_{12}$ uptake by brush borders and microvillous membranes prepared from hamster ileum, human IF is ineffective (2). On the other hand, human IF enhances intestinal uptake of the vitamin in the guinea pig $(3,4)$. To study human IF, we prepared microvillous membranes from guinea pig ileum, and demonstrate here that these membranes contain receptor sites for vitamin $B_{12}$ bound to human IF.

Previous studies indicate that attachment of IF to its receptor site occurs rapidly, is not impaired by metabolic inhibitors, and requires calcium ions and a $\mathrm{pH}$ higher than $6.0(5,6)$. Nevertheless, quantitative data concerning the kinetics of binding of IF to its receptor are lacking. Furthermore, there is little information on the relationship between the binding of $\mathrm{B}_{12}$ by $\mathrm{IF}$ and the interaction of IF with receptor. In particular, controversy exists as to whether IF, in the absence of vitamin $\mathrm{B}_{12}$, competes with $\mathrm{IFB}_{12}$ for ileal surface receptors $(7,8)$. In the present investigation, we have systematically examined the kinetics of $\operatorname{IFB}_{12}$ uptake by guinea pig brush borders and have compared attachment of $I F B_{13}$ with that of IF alone and with that of IF complexed with various analogs of vitamin $B_{12}$.

\section{METHODS}

Intrinsic factor $I F$. Gastric juice was obtained from patients with peptic disease who required Histalog-stimulated tests of gastric secretion (Eli Lilly \& Co., Indianapolis, Ind.). Pepsin was inactivated as described previously (9). A single large pool of gastric juice from several patients was divided into small portions and stored at $-20^{\circ} \mathrm{C}$. The total $\mathrm{CN}-\mathrm{Cbl}$ (cobalamin) binding capacity of this pool was $81.5 \mathrm{ng} / \mathrm{ml}$, as determined by exhaustive dialysis (10). Serum containing blocking antibody (11) to IF abolished $97 \%$ of this total binding capacity. The remaining $3 \%$ of binding was shown by chromatography on DEAE cellulose to be due to "R binder" (12).

Cobamides. ${ }^{\circ 0} \mathrm{Co}$-labeled $\mathrm{CN}-\mathrm{Cbl}(2.8 \mathrm{mCi} / \mathrm{mg})$ was purchased from E. R. Squibb \& Sons, New York. Unlabeled $\mathrm{CN}-\mathrm{Cbl}$ and adenosylcobalamin (AdoCbl) were purchased from Sigma Chemical Co., Inc., St. Louis, Mo. Methylcobalamin $(\mathrm{MeCbl})$ was synthesized by the alkylation of cob(I)alamin with methyl iodide, as described by Johnson, Mervyn, Shaw, and Smith (13). Hydroxocobalamin (OHCb1) was prepared by aerobic photolysis of an aqueous solution of methylcobalamin (14). The solution of aquocobalamin so prepared was taken to dryness on a rotary evaporator to remove volatile products derived from the methyl group.

$\alpha$-(Adenyl) cobamide cyanide [(Ade) $\mathrm{CN}$-Cba; "pseudo $\mathrm{B}_{12}$ "] was obtained from the microorganism that synthesizes ethanolamine ammonia-lyase, a $\mathrm{B}_{12}$-dependent enzyme (15). When isolated from the microorganism, this enzyme carries a substantial quantity of bound Ado:(Ade) AdoCba. The cobamide was released from the enzyme by treatment with acid-ammonium sulfate (15) and was photolyzed to aquo- $\alpha$-(adenyl)cobamide. Liquified phenol was used to extract the cobamide from the aqueous acid-ammonium sulfate phase. The phenol layer was washed, and the cobamide was extracted back into the water by the technique of Barker (16). To convert the aquo- $\alpha$-(adenyl) cobamide into $\alpha$ (adenyl)cobamide cyanide, a small crystal of $\mathrm{NaCN}$ was added to the solution, after which the solution was acidified with $0.1 \mathrm{~N} \mathrm{HCl}$. The product was extracted into the phenol, the phenolic solution washed twice with water to remove excess $\mathrm{NaCN}$, and the cobamide was extracted back from phenol into water as described above.

$\alpha$-(5,6-dimethylbenzimidazole)-cobamic acid a,b,c,d,g,pentaamide cyanide [cyanocobalamin minus the e-amide group; $\mathrm{CN}-\mathrm{Cbl}(\mathrm{OH})^{\mathrm{e}}$ ] was prepared by the method of Bernhauer, Wagner, Beisbarth, Rietz, and Vogelmann (17). Cyanocobalamin $(3 \mathrm{mg}$ ) was dissolved in $5 \mathrm{ml}$ of $0.02 \mathrm{~N}$ $\mathrm{HCl}$. This solution was permitted to stand at room temperature for 4 days, after which the products were extracted into phenol and then back-extracted into water, as described by Barker (16). The $\mathrm{B}_{12}$ derivatives were then applied to Whatman $3 \mathrm{MM}$ paper and subjected to descending chromatography for $24 \mathrm{~h}$. Chromatograms were developed with water-saturated sec-butanol:glacial acetic acid (99:1), containing $20 \mathrm{mg} \mathrm{KCN} / 100 \mathrm{ml}$. The component with the highest mobility $\left(\mathrm{R}_{\mathrm{CN}-\mathrm{Cbl}}=1.7\right)$, identified as the desired compound from the data of Bernhauer, et al. (17), was eluted with water. Removal of the last traces of $\mathrm{KCN}$ was accomplished by extraction into phenol, followed by back-extraction into water as described above.

Cyanoaquocobinamide $[(\mathrm{CN}, \mathrm{OH}) \mathrm{Cbi}$ ] was prepared from aquocobinamide formed by the aerobic photolysis of cobinamide coenzyme. The latter was the generous gift of Prof. J. M. Wood. No attempt was made to separate the corrin from the adenosyl derivatives formed during photolysis (18). Aquocobinamide was converted to cyanoaquocobinamide by the technique used for the conversion of aquo- $\alpha-$ (adenyl) cobalamin to $\alpha$-(adenyl) cobalamin cyanide.

The concentrations of unlabeled cobamides were determined spectrophotometrically at $367 \mathrm{~nm}$ after conversion to the cobamide dicyanides by photolysis, followed by the addition of a crystal of solid $\mathrm{KCN}$ to the cuvette. The molar extinction coefficient was taken as $30,400 \mathrm{~cm}^{2} \mathrm{~mol}^{-1}$ (19).

Isolation of brush borders and microvillous membranes. Brush borders were isolated from guinea pig intestine as previously described for the hamster (2). All procedures were carried out in a cold room at $4^{\circ} \mathrm{C}$. Guinea pigs weighing $300-400 \mathrm{~g}$ were killed by a blow to the head. The small bowel was immediately removed and divided into proximal and distal halves. Each half was washed separately by flushing with cold $5 \mathrm{mM}$ EDTA in $0.15 \mathrm{M}$ sodium phosphate buffer, $\mathrm{pH}$ 7.0. The mucosa was expressed from the washed intestinal segments by pressing on the serosal surface of the bowel with a glass rod. Mucosa from either the proximal or the distal half of four to six intestines was pooled in $100 \mathrm{ml}$ of EDTA solution and homogenized in a Waring Blendor (Waring Products Div., Dynamics Corp. of America, New Hartford, Conn.) for $25 \mathrm{~s}$. The speed and time of homogenization required for optimal brush border preparations was determined experimentally and found to be the same as previously described for the hamster (2). The homogenate was filtered through No. 2 bolting silk (Tobler, Ernst \& Trabler, Inc., New York), and the filtrate was centrifuged in an International refrigerated centrifuge (Damon/IEC Div., Damon Corp., Needham Heights, Mass.) at $1,500 \mathrm{rpm}$ for $10 \mathrm{~min}$. The pellet was washed twice by carefully resuspending it in cold EDTA solution and centrifuging at 1,500 rpm to remove lighter contaminating particles. The final pellet 
was resuspended in cold EDTA solution and centrifuged at $500 \mathrm{rpm}$ for $1 \mathrm{~min}$ to remove any remaining nuclei and intact cells. The supernate was then centrifuged for 10 $\min$ at 2,500 $\mathrm{rpm}$ and the precipitate was resuspended in Krebs-Ringer bicarbonate (KRB) buffer at $\mathrm{pH}$ 7.4. Phase contrast microscopy was used to assess the purity of each brush border preparation.

Microvillous membranes were prepared from brush borders by disruption with Tris, followed by density gradient centrifugation as described by Eichholz and Crane (20) After density gradient centrifugation, only a broad $\mathrm{C}$ band containing microvillous membranes was observed. The $\mathrm{C}^{1}$ band seen in hamster preparations $(2,20)$ was not evident. The purity of microvillous membranes was established by electron microscopy, as previously described (2).

Binding of $\left[{ }^{60} \mathrm{Co}\right] \mathrm{CN}-\mathrm{Cbl}$ to $I F$. All binding experiments were done in $0.9 \%$ saline buffered at $\mathrm{pH} 7.4$ with $0.01 \mathrm{M}$ potassium phosphate buffer. Portions of the gastric juice pool were thawed and diluted with the buffer to give a final concentration of $0.19 \mathrm{mg}$ of protein $/ \mathrm{ml}$. Binding was measured in test tubes by placing $2 \mathrm{ml}$ of this dilute gastric juice into a cellulose dialysis bag (Arthur H. Thomas Co. Philadelphia) and dialyzing this against $2 \mathrm{ml}$ of buffered saline that contained free $\left[{ }^{80} \mathrm{Co}\right] \mathrm{CN}-\mathrm{Cbl}$ in concentrations ranging from 0.3 to $8.0 \mathrm{nM}$. Preliminary experiments with saline inside the dialysis bag showed that equilibrium was attained when tubes were rotated on a wheel at $15 \mathrm{rpm}$ for $18 \mathrm{~h}$ at room temperature. For each binding assay, equilibration was monitored by including tubes with saline instead of gastric juice inside the bag. After dialysis, 1-ml portions from the bag and from the outside fluid were counted in a Packard Auto-Gamma detector (Packard Instrument Co., Inc., Downers Grove, IIl.). The concentration of unbound $\mathrm{CN}-\mathrm{Cbl}$ was equal to that measured in the outside fluid. The amount of $\mathrm{CN}-\mathrm{Cbl}$ inside the bag was equal to the sum of the unbound $\mathrm{CN}-\mathrm{Cbl}$ plus that bound to IF. In calculating the binding of $\mathrm{CN}-\mathrm{Cbl}$ to IF, the assumption was made that the concentration of protein inside the bag did not change during the course of the dialysis.

Inhibition of $\left[{ }^{60} \mathrm{Co}\right] \mathrm{CN}-\mathrm{Cbl}$ binding to IF by cobamides. Equilibrium dialysis was carried out as described above, but in these experiments dilute gastric juice was dialyzed against a series of solutions containing a fixed amount of the cobamide under investigation, together with increasing concentrations of $\left[{ }^{\infty} \mathrm{Co}\right] \mathrm{CN}-\mathrm{Cbl}$. The $K_{\mathfrak{l}}$ for the analog was determined either with the aid of the Scatchard plot (21), or by means of the following equation, which is derived in the Appendix:

$$
\frac{\left[I_{t}\right]}{\frac{K_{L}[L]}{Y}-K_{L}[L]-1}=\frac{Y}{K_{L}[L]}\left[E_{t}\right]+K_{i}
$$

$\left[I_{t}\right]=$ total concentration of inhibitor $;\left[E_{t}\right]=$ total concentration of IF ; $K_{L}=$ association constant for the formation of the CN-Cbl. IF complex; $[L]=$ concentration of $\left[{ }^{\infty 0} \mathrm{Co}\right]-$ $\mathrm{CN}-\mathrm{Cbl}$; and $Y=$ fractional saturation of total IF binding sites.

Preparation of the cobamide.IF complexes used in binding studies with ileal receptor. An excess of $\left[{ }^{57} \mathrm{Co}\right] \mathrm{CN}-\mathrm{Cbl}$ was added to thawed portions of the gastric juice pool and incubated at room temperature for $30 \mathrm{~min}$. The mixture was then dialyzed at $4^{\circ} \mathrm{C}$ for $48 \mathrm{~h}$ against two changes of 3 liters each of $0.9 \%$ saline to remove excess unbound $B_{12}$. Suitable dilutions of the dialyzed material were prepared and stored at $-20^{\circ} \mathrm{C}$. Complexes of IF with vitamin $\mathrm{B}_{12}$ analogs were similarly prepared and diluted. Saturation of all available binding sites by the analog was established by the observation that when $\left[{ }^{80} \mathrm{Co}\right] \mathrm{CN}-\mathrm{Cbl}$ was added to the preparation, no ${ }^{80} \mathrm{Co}$ was bound to IF. Free IF was prepared by incubation and dialysis of gastric juice as described above, except that cobamide was omitted.

Complexes of vitamin $\mathrm{B}_{12}$ with non-IF binding proteins on human saliva, gastric juice, and serum were prepared by DEAE column chromatography (12) after saturation of binders with $\left.{ }^{57} \mathrm{Co}\right] \mathrm{CN}-\mathrm{Cbl}$.

Removal of cobamide-binding proteins from the IF preparation by affinity chromatography. In certain experiments, a preparation of IF was used from which cobamide-binding proteins were specifically removed by passage through a vitamin $B_{12}$-Sepharose column prepared by the method of Allen and Majerus (22). For these experiments, the IF preparation was subjected to chromatography as follows: Two columns were poured, one containing $0.2 \mathrm{ml}$ of vitamin $\mathrm{B}_{12}$-Sepharose (the affinity column), the other containing

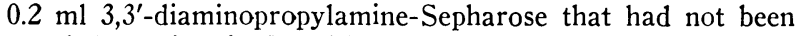
coupled to vitamin $B_{12}$ (the control column). Each column was washed with $5 \mathrm{ml}$ of $0.1 \mathrm{M}$ potassium phosphate buffer, $\mathrm{pH} 7.4 .2 \mathrm{ml}$ of IF (original $\mathrm{CN}-\mathrm{Cbl}$ binding capacity 28.3 $\mathrm{ng} / \mathrm{ml})^{2}$ was then passed through each column. After chromatography, the $\mathrm{CN}-\mathrm{Cbl}$ binding capacities of the IF from the control and affinity columns were 27.5 and $<0.001$ $\mathrm{ng} / \mathrm{ml}$, respectively. The preparation from the control column was diluted with $0.155 \mathrm{M} \mathrm{NaCl}$ to a $\mathrm{CN}-\mathrm{Cbl}$ binding capacity of $2.0 \mathrm{ng} / \mathrm{ml}$. The IF-depleted preparation was diluted to the same extent.

Vitamin $B_{12}$ uptake by tissue preparations. Freshly prepared mucosal homogenates, brush borders, or microvillous membranes were resuspended in cold KRB. Volumes were adjusted so that tissue protein concentrations were $0.6-0.9$ $\mathrm{mg} / \mathrm{ml}$ for brush borders and $0.1-0.2 \mathrm{mg} / \mathrm{ml}$ for microvillous membranes. Tissue protein concentration was determined by the method of Lowry, Rosebrough, Farr, and Randall (23). 1-ml portions of suspension were added to $16 \times 250-\mathrm{mm}$ polyethylene counting tubes containing, unless otherwise indicated, $2 \mathrm{ng}$ of free or IF-bound $\left[{ }^{57} \mathrm{Co}\right] \mathrm{CN}-\mathrm{Cbl}$. The reaction mixtures were adjusted to $5 \mathrm{ml}$ with $\mathrm{KRB}$ and incubated in a shaking water bath at $37^{\circ} \mathrm{C}$. After incubation, an excess of cold KRB was added, and the tubes were centrifuged at $2500 \mathrm{rpm}$ for $10 \mathrm{~min}$ at $4^{\circ} \mathrm{C}$. The precipitate was washed twice in cold $\mathrm{KRB}$, and the radioactivity taken up by the tissue was determined in a Packard Autogamma detector.

For measurements of attachment of $\mathrm{IFB}_{12}$ to membrane receptors at early time intervals, the free $I_{F B_{12}}$ was separated from the attached complex by filtration. Reaction mixtures contained brush borders, IF-bound $\left[{ }^{57} \mathrm{Co}\right] \mathrm{CN}-\mathrm{Cbl}$, and $\mathrm{KRB}$ as described above. Incubations were performed in a Millipore filtration apparatus containing a Millipore glass fiber filter $(2.5 \mathrm{~cm}$ diameter, Millipore Corp., Bedford, Mass.). For the incubation, the apparatus was placed in the mouth of a sidearm flask connected by a rubber hose to a continuously running water aspirator. During the incubation the filtration apparatus was isolated from the vacuum by a pinch clamp on the hose. The incubation was terminated by removing the clamp, causing the soluble portion of the incubation mixture to be drawn rapidly into the

${ }^{2}$ The experiments using this material were performed many months after the rest of the experiments reported in this paper were completed. In that time, the $\mathrm{CN}$-Cbl binding capacity of the IF preparation fell to $35 \%$ of its initial value. 
flask. Immediately, the brush borders retained on the filter were washed with $25 \mathrm{ml}$ of cold KRB. The filter was then dried and placed in a polyethylene tube for determination of radioactivity.

Binding of analog. IF complexes to guinea pig receptor was measured by incubating fresh preparations of brush borders for $1 \mathrm{~h}$ with increasing concentrations of $\left[{ }^{57} \mathrm{Co}\right]-$ $\mathrm{CN}-\mathrm{Cbl}$ complex in the presence of a quantity of analog. IF complex containing $1.5 \mathrm{pmol}$ of analog. Incubations were performed in KRB solution as described above. Brush borders were separated from the soluble portion of the reaction mixture by centrifugation. In each set of experiments, paired control tubes without analog.IF complex were incubated to determine the $K_{d}$ for the complex between receptor and $\left[{ }^{57} \mathrm{Co}\right] \mathrm{CN}-\mathrm{Cbl} \cdot \mathrm{IF}$ complex in the absence of analog. IF complex.

Protection from photolysis. All manipulations of Coalkyl cobamides were conducted in dim light, and all equilibrium dialyses were conducted in the dark, to prevent destruction of these compounds by light.

\section{RESULTS}

The interaction between cobamides and human intrinsic factor

Binding of $\mathrm{CN}-\mathrm{Cbl}$ to $I F$. The binding of $\mathrm{CN}-\mathrm{Cb}$ to IF showed saturation kinetics. A Scatchard plot of the binding data (Fig. 1) shows that the IF present in 1 $\mathrm{mg}$ (23) of gastric juice protein bound $17 \mathrm{pmol}$ of $\mathrm{CN}-\mathrm{Cbl}$. Binding in excess of this amount may have been due to the small concentration of $\mathrm{R}$ binder known to be present in the IF preparation used. Considerable deviation from linearity was observed at low concentrations of $\mathrm{CN}-\mathrm{Cbl}$, when the IF was less than half saturated. Whether this deviation from linearity was a true property of the interaction between IF and $\mathrm{CN}-\mathrm{Cbl}$ or an artifact of the assay was not investigated further. The dissociation constant $\left(K_{d}\right)$ for the $\mathrm{CN}-\mathrm{Cbl} \cdot \mathrm{IF}$ complex was calculated from the linear portion of the Scatchard plot and was found to be $0.066 \mathrm{nM}$. This figure agrees with that previously reported by McGuigan (24).

Binding of other cobamides to IF. The binding of vitamin $B_{12}$ analogs to IF was determined by competition experiments. Preliminary experiments showed that the

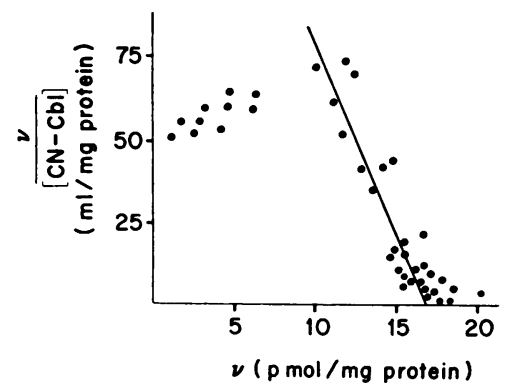

Figure 1 Scatchard plot of the binding of $\left[{ }^{\circ} \mathrm{Co}\right] \mathrm{CN}-\mathrm{Cb} 1$ to IF.

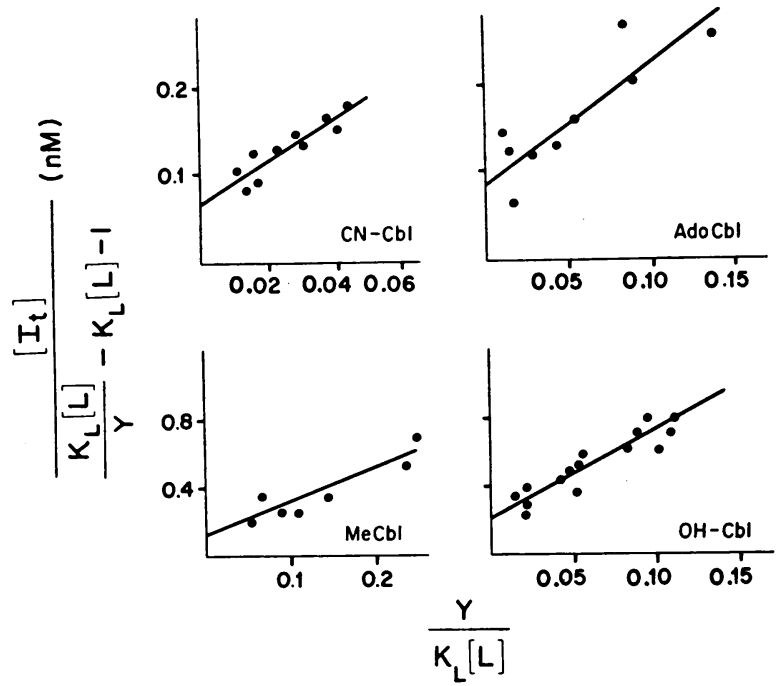

Figure 2 Binding of high-affinity $\mathrm{B}_{12}$ analogs to IF. Regression lines were fitted by the method of least squares, using $14(\mathrm{nM})^{-1}$ as the value of $K_{L}$. For further details, see text.

analogs fell into two categories: those whose affinities for IF were similar to that of $\mathrm{CN}-\mathrm{Cbl}$ and those with an affinity much lower than that of $\mathrm{CN}-\mathrm{Cbl}$. Binding constants for those $B_{12}$ derivatives in the former category were calculated by the equation derived in the Appendix. Fig. 2 shows data plotted according to this equation for these "high-affinity" analogs. The $K_{1}$ obtained from the $y$-intercept of each plot is given in Table I. When unlabeled $\mathrm{CN}-\mathrm{Cbl}$ was used as a high-affinity inhibitor of the binding of $\left[{ }^{\infty} \mathrm{Co}\right] \mathrm{CN}-\mathrm{Cbl}$, the $K_{i}(0.067 \mathrm{nM})$ was virtually identical to the $K_{d}$ of $\mathrm{CN}-\mathrm{Cbl}$ as measured directly by equilibrium dialysis $(0.066 \mathrm{nM})$, an observation supporting the validity of the equation under the experimental conditions. The values of $K_{1}$ for the rest of the high-affinity analogs indicate that the affinity of each of these analogs for IF is similar to that of $\mathrm{CN}-\mathrm{Cbl}$.

The slopes of the regression lines (Table I) obtained with $\mathrm{CN}-\mathrm{Cbl}, \mathrm{MeCbl}$, and $\mathrm{AdoCbl}$ agree closely with the concentration of IF in the system $(1.6 \mathrm{nM}$, calculated on the basis of the total volume of the system, in-

TABLE I

Inhibition Conslants of High-Affinity Vitamin $B_{12}$ Analogs

\begin{tabular}{lll}
\hline \multicolumn{1}{c}{ Analog } & Slope & \multicolumn{1}{c}{$K_{I}$} \\
\hline & $n M$ & \multicolumn{1}{c}{$n M$} \\
{$\left[{ }^{60} \mathrm{Co}\right] \mathrm{CN}-\mathrm{Cbl}$} & - & $0.066^{*}$ \\
$\mathrm{CN}-\mathrm{Cbl}$ & 2.3 & 0.067 \\
OH-Cbl & 4.9 & 0.23 \\
MeCbl & 1.8 & 0.13 \\
AdoCbl & 1.4 & 0.093 \\
\hline
\end{tabular}

${ }^{*} K_{d}$ measured directly by equilibrium dialysis.

Attachment of Cobamides to Ileal Receptor 
TABLE II

Inhibition Constants for Low-Affinity Cobamide. IF Complexes

\begin{tabular}{ccc}
\hline Cobamide & $R_{\mathrm{CN} . \mathrm{Cb}{ }^{*}}$ & \multicolumn{1}{c}{$K_{\boldsymbol{i}}$} \\
\hline & & $n M$ \\
$(\mathrm{Ade}) \mathrm{CN}-\mathrm{Cba}$ & 0.39 & 9.9 \\
$\mathrm{CN}-\mathrm{Cbl}(\mathrm{OH})^{\mathrm{e}}$ & 1.56 & 33 \\
$(\mathrm{CN}, \mathrm{OH}) \mathrm{Cbi}$ & 1.85 & $>10,000$
\end{tabular}

$* R_{\mathrm{CN}-\mathrm{Cbl}}=$ mobility of cobamide/mobility of $\mathrm{CN}-\mathrm{Cbl}$.

cluding fluid both inside and outside the dialysis bag). This finding indicates that each of the analogs inhibits binding of $\left[{ }^{80} \mathrm{Co}\right] \mathrm{CN}-\mathrm{Cbl}$ to $\mathrm{IF}$ in a simple competitive manner (see Appendix). With $\mathrm{OH}-\mathrm{Cbl}$, however, the slope of the regression line was $4.9 \mathrm{nM}$, suggesting that with this analog, inhibition was not strictly competitive.

For those analogs with a low affinity for IF, it was possible to determine the dissociation constants by Scatchard plots, because at levels required to show inhibition, the concentration of unbound analog closely approximated total analog concentration. Because the apparent affinity of these compounds for IF was so low, the question was raised as to whether the inhibition demonstrated by these preparations might not actually be due to contamination with trace amounts of unlabeled CN-Cbl. To investigate this possibility, these analogs were tested both before and after repurification by paper chromatography. For this purpose, Whatman $3 \mathrm{MM}$ paper was used. Chromatograms were developed for $24 \mathrm{~h}$ by the descending technique with a solvent system consisting of sec-butanol/glacial acetic acid/water/ $10 \%$ (wt $/ \mathrm{vol}) \mathrm{KCN}=75 / 1 / 25 / 0.1(\mathrm{vol} / \mathrm{vol})$. The ana-

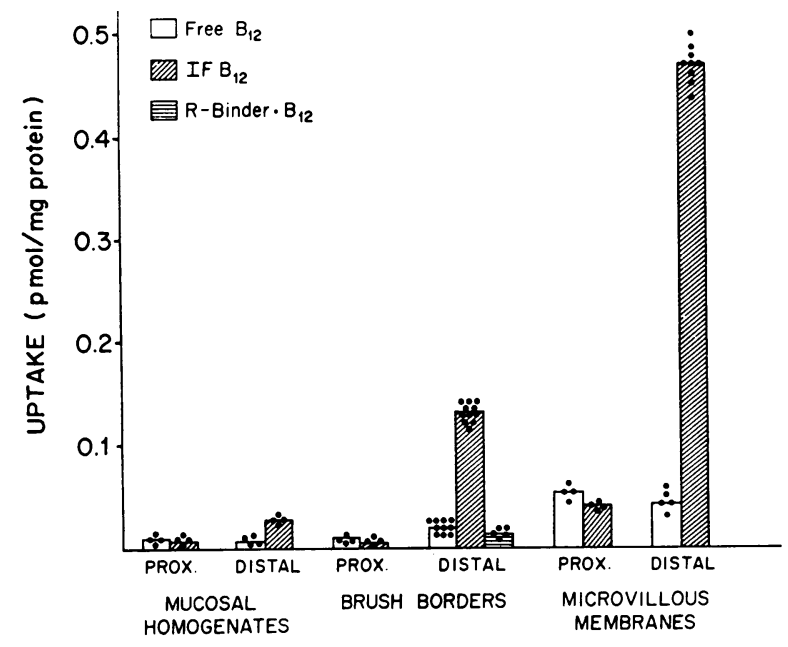

Figure 3 Binding of $\left[{ }^{67} \mathrm{Co}\right] \mathrm{CN}-\mathrm{Cb} 1$ by preparations from guinea pig intestinal mucosa. Points represent results of individual experiments and bars the mean values. The same pool of neutralized human gastric juice was used in all experiments. logs were eluted with water, desalted by extraction into phenol and back-extraction in water, and again tested for their ability to inhibit the binding of $\mathrm{CN}-\mathrm{Cbl}$ to $\mathrm{IF}$. Table II shows the $R_{\mathrm{CN}-\mathrm{Cb}}$ values and the inhibition constants for the repurified analogs. From the $R_{\mathrm{CN}-\mathrm{Cb}}$ values it is apparent that the repurification procedure was suitable for removing contaminating $\mathrm{CN}-\mathrm{Cbl}$ from the analog preparations. The dissociation constants of (Ade) $\mathrm{CN}-\mathrm{Cba}$ and $\mathrm{CN}-\mathrm{Cbl}(\mathrm{OH})^{\circ}$ were found to be unchanged by purification, whereas the apparent inhibition observed with the original preparation of $(\mathrm{CN}$, $\mathrm{OH}) \mathrm{Cbi}$ was abolished by purification. Thus, (Ade)$\mathrm{CN}-\mathrm{Cba}$ and $\mathrm{CN}-\mathrm{Cbl}(\mathrm{OH})^{\circ}$ appear to bind to IF, albeit with a comparatively low affinity, while $(\mathrm{CN}, \mathrm{OH})$ $\mathrm{Cbi}$ does not bind to IF at concentrations as high as $10^{-5} \mathrm{M}$.

The binding of the IF - cobamide complex to the ileal receptor

Attachment of CN-Cbl.IF to guinea pig ileal receptor. Human IF enhanced the uptake of $\left[{ }^{57} \mathrm{Co}\right] \mathrm{CN}-\mathrm{Cbl}$ by all preparations obtained from the distal half of guinea pig small bowel (Fig. 3). In terms of uptake per milligram of tissue protein, brush borders took up four times as much $I_{1 F B}$ as crude mucosal homogenates, while uptake of microvillous membranes was 16 times that of homogenates. By contrast, uptake of $\mathrm{IFB}_{12}$ by tissue preparations from proximal small intestine was consistently less than that of the free vitamin. On the other hand, salivary, gastric, and serum vitamin $\mathrm{B}_{12}$-binding proteins lacking IF activity ( $\mathrm{R}$ binders) were found to be completely ineffective in promoting attachment of $\left[{ }^{57} \mathrm{Co}\right]$ $\mathrm{CN}-\mathrm{Cbl}$ to distal brush borders.

Attachment of human $\mathrm{IFB}_{12}$ complex to ileal microvillous membranes displayed saturation kinetics. From a reciprocal plot of uptake versus concentration of $\mathrm{IFB}_{12}$ (Fig. 4), the dissociation constant for the reaction $\mathrm{IFB}_{12}$

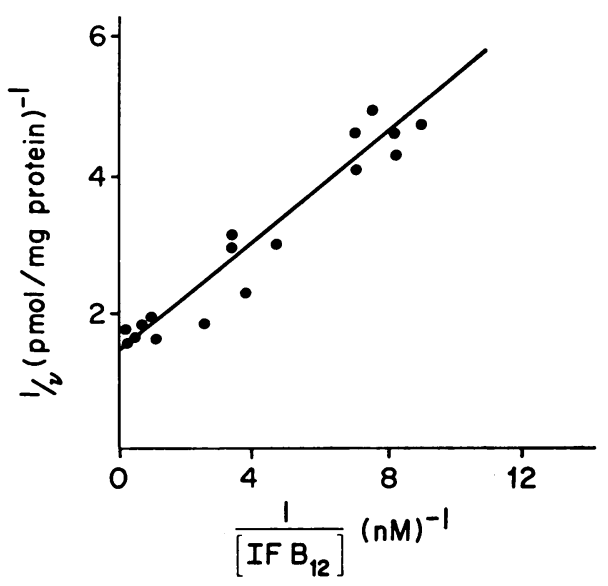

FIgURE 4 Reciprocal plot of binding of $\mathrm{IFB}_{12}$ to microvillous membranes as a function of IFB $_{12}$ concentration. 


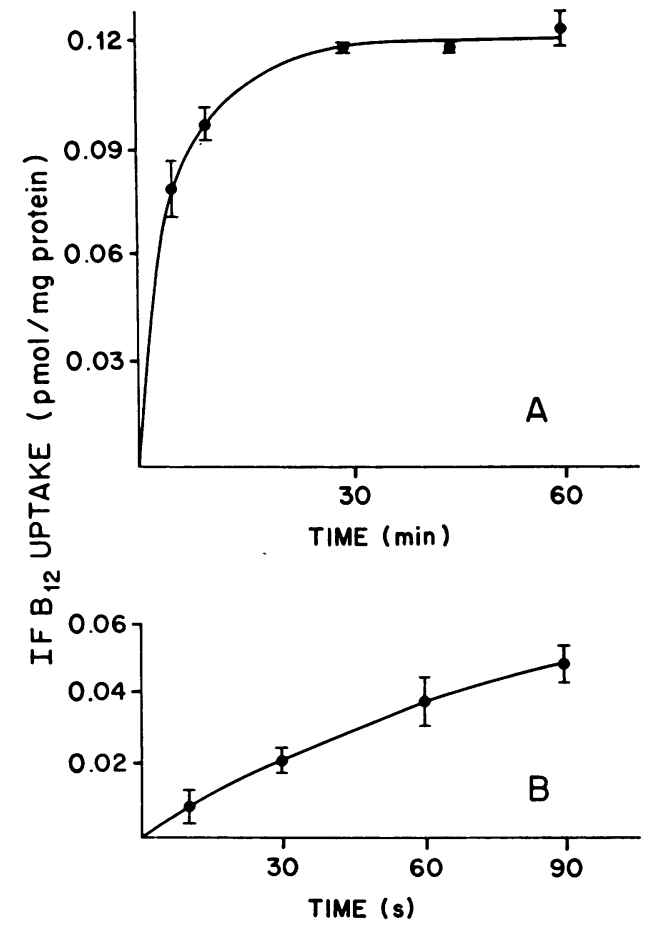

Figure 5 Rate of uptake of $\mathrm{IFB}_{12}$ by brush borders. Uptake by brush borders of $\left[{ }^{57} \mathrm{Co}\right] \mathrm{CN}-\mathrm{Cbl}$ bound to IF was measured as a function of time. Reaction mixtures contained $1.15 \mathrm{nM} \mathrm{IFB}_{12}$ complex and a quantity of brush border suspension containing $1 \mathrm{mg}$ tissue protein. Error bars indicate $\pm 1 \mathrm{SD}$. A, Attached $\mathrm{IFB}_{12}$ separated by centrifugation (see Methods); B, Early uptakes measured by separating attached $\mathrm{IFB}_{12}$ by filtration (see Methods).

+ receptor $\rightleftharpoons \mathrm{IFB}_{12} \cdot$ receptor was determined to be 0.25 nM. Similar values were obtained for attachment of human IFB $_{12}$ complex to mucosal homogenates and brush borders ( $0.21 \mathrm{nM}$ and $0.30 \mathrm{nM}$, respectively).

The rate of attachment of human $\mathrm{IFB}_{12}$ complex to brush border receptor was determined by measuring uptake at a given concentration of $\mathrm{IFB}_{12}$ as a function of time. The first experiments, in which centrifugation was used to separate unattached IFB ${ }_{12}$ from $I F B_{12}$ bound to receptor, showed that the binding reaction was about $70 \%$ complete at $5 \mathrm{~min}$ (Fig. 5A). The initial rate of attachment was determined more precisely by measuring uptake at earlier time intervals. For this purpose a rapid filtration assay was developed (see Methods). From measurements made over the first $90 \mathrm{~s}$ (Fig. 5B), an initial rate of uptake of approximately $0.05 \mathrm{pmol} / \mathrm{mg}$ protein per min was seen at a concentration of $\mathrm{IFB}_{12}$ complex of $1.15 \mathrm{nM}$. From the data of Fig. 4, the total binding capacity of microvillous membranes for $\operatorname{IFB}_{12}$ at a concentration of $1.15 \mathrm{nM}$ is $0.55 \mathrm{pmol} / \mathrm{mg}$ protein. The second-order rate constant for the attachment of $\mathrm{IFB}_{12}$ to receptor is therefore $1.3 \times 10^{6} \mathrm{M}^{-1} \mathrm{~s}^{-1}$. From this value and the previously determined thermodynamic

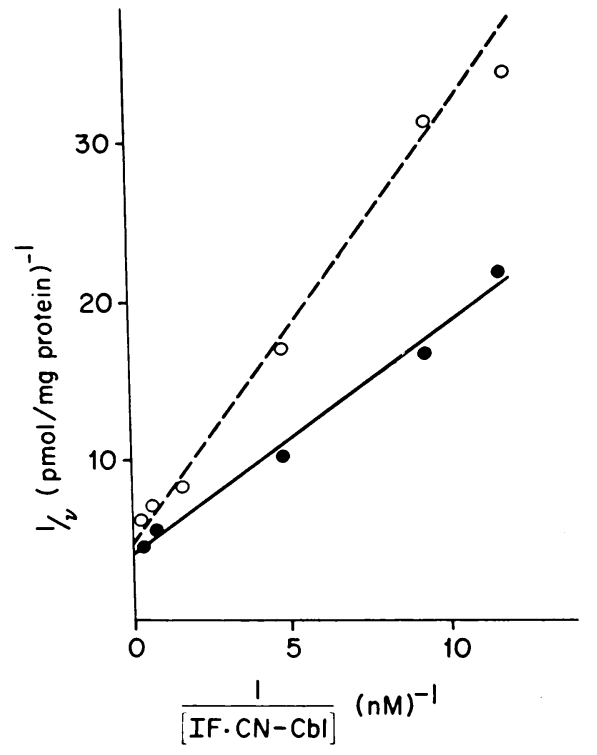

Figure 6 Inhibition by OH-Cbl-IF of the attachment of $\left[{ }^{57} \mathrm{Co}\right] \mathrm{CN}-\mathrm{Cbl} \cdot \mathrm{IF}$ to the ileal receptor.

dissociation constant, the rate of dissociation of $\mathrm{IFB}_{12}$ from the receptor can be calculated to be $1.2 \mathrm{~h}^{-1}$.

Attachment to ileal receptor of complexes between IF and other $B_{12}$ derivatives. Nonradioactive $\mathrm{CN}-\mathrm{Cbl} \cdot \mathrm{IF}$ complex competitively inhibited uptake of $\left[{ }^{57} \mathrm{Co}\right] \mathrm{CN}-\mathrm{Cbl}$. IF complex by brush borders isolated from guinea pig ileum. The $K_{\imath}$ with unlabeled $\mathrm{CN}-\mathrm{Cbl}$ calculated from this experiment $(0.30 \mathrm{nM})$ was the same as the $K_{d}$ of $\left[{ }^{57} \mathrm{Co}\right] \mathrm{CN}-\mathrm{Cbl} \cdot \mathrm{IF}$ for the ileal receptor. Reciprocal plots of binding data showed that all of the other cobamide-IF complexes tested also inhibited attachment of $\left[{ }^{57} \mathrm{Co}\right] \mathrm{CN}-\mathrm{Cbl} \cdot \mathrm{IF}$ complex to the receptor competitively. As an example, Fig. 6 shows a reciprocal plot of the effect of $\mathrm{OH}-\mathrm{Cbl} \cdot \mathrm{IF}$ complex on the attachment of $\left[{ }^{57} \mathrm{Co}\right] \mathrm{CN}-\mathrm{Cbl} \cdot \mathrm{IF}$ complex. The calculated inhibition constants for the various cobamide.IF complexes are presented in Table III. Complexes of IF with $\mathrm{OH}-\mathrm{Cbl}$, $\mathrm{MeCbl}, \mathrm{AdoCbl}$, and $\mathrm{CN}-\mathrm{Cbl}(\mathrm{OH})^{\mathbf{e}}$ had the same affinity as $\mathrm{CN}-\mathrm{Cbl} \cdot \mathrm{IF}$ complex for the receptor, while the

TABLE III

Inhibition of the Attachment of $\left[{ }^{57} \mathrm{Co}\right] \mathrm{CN}-\mathrm{Cbl} \cdot \mathrm{IF}$ to Receptor by Analog. IF Complexes

\begin{tabular}{lc}
\hline \multicolumn{1}{c}{ Analog } & $K_{i}$ \\
\hline & $n . M$ \\
CN-Cbl & 0.30 \\
OH-Cbl & 0.22 \\
MeCbl & 0.29 \\
AdoCbl & 0.15 \\
CN-Cbl $(\mathrm{OH})^{\mathrm{e}}$ & 0.46 \\
(Ade)CN-Cba & 0.99 \\
\hline
\end{tabular}

Attachment of Cobamides to Ileal Receptor 
TABLE IV

Inhibition by Free IF of the Attachment of $I F B_{12}$ Complex to Brush Border Receptor

\begin{tabular}{clc}
\hline $\begin{array}{c}\text { Preliminary } \\
\text { incubation }\end{array}$ & \multicolumn{1}{c}{$\begin{array}{c}\text { Final } \\
\text { incubation }\end{array}$} & Uptake \\
\hline & & $\begin{array}{c}\text { pmol/mg } \\
\text { tissue protein }\end{array}$ \\
- & $\mathrm{IFB}_{12}$ & 0.118 \\
$\mathrm{IF}$ & $\mathrm{IFB}_{12}$ & 0.081 \\
- & ${\mathrm{IF} \mathrm{and} \mathrm{IFB}_{12}}$ & 0.124 \\
$\mathrm{IF}$ & $\mathrm{B}_{12}$ & 0.015 \\
$\mathrm{~B}_{12}$ & 0.023 \\
\hline
\end{tabular}

During the preliminary incubation, brush borders were incubated for $1 \mathrm{~h}$ at room temperature in $5 \mathrm{ml}$ of $\mathrm{KRB}$, which, where indicated, contained 1.5 pmol free IF. Brush borders were then centrifuged, washed in $\mathrm{KRB}$, and resuspended in $5 \mathrm{ml} \mathrm{KRB}$ containing $1.5 \mathrm{pmol}$ of either free $\left[{ }^{57} \mathrm{Co}\right] \mathrm{CN}-\mathrm{Cbl}$ or $\left[{ }^{57} \mathrm{Co}\right] \mathrm{CN}-\mathrm{Cbl}$ complexed with $\mathrm{IF}\left(\mathrm{IFB}_{12}\right)$ and, where indicated, with $1.5 \mathrm{pmol}$ of free IF. After this final incubation for $1 \mathrm{~h}$ at $37^{\circ} \mathrm{C}$, uptake of radioactivity was determined by the method of centrifugation (see Methods).

$K_{\imath}$ for (Ade) CN-Cbl-IF complex was somewhat less than that of the other cobamide complexes.

Attachment of free IF to the ileal receptor. To determine whether IF not bound to vitamin $B_{12}$ attaches to the ileal surface, we measured the uptake of radioactive $\mathrm{IFB}_{12}$ complex by distal brush borders in the presence and absence of free IF. In these experiments, uptake of IFB $_{12}$ complex by brush borders preincubated for $1 \mathrm{~h}$ with free IF was compared with uptake when $I F B_{12}$ and free IF were added simultaneously. The results (Table IV) show that inhibition of IFB $_{12}$ uptake by an equivalent amount of free IF is observed if the brush borders are preincubated with the free IF.

TABLE V

Failure of IF Preparation Passed through a Vitamin

$B_{12}$-Sepharose Column to Inhibit the Attachment of $I F B_{12}$ Complex to Brush Border Receptor

\begin{tabular}{ccc}
\hline \multicolumn{2}{c}{ IF preparation } & \\
\cline { 2 - 3 } $\begin{array}{c}\text { Preliminary } \\
\text { incubation }\end{array}$ & $\begin{array}{c}\text { Final } \\
\text { incubation }\end{array}$ & Uptake \\
\hline & & $\begin{array}{c}\text { pmol } / \mathrm{mg} \\
\text { tissue protein }\end{array}$ \\
- & - & $0.016 \pm 0.004$ \\
- & Control & $0.120 \pm 0.017$ \\
- & IF-depleted & $0.012 \pm 0.003$ \\
Control & Control & $0.052 \pm 0.002$ \\
IF-depleted & Control & $0.125 \pm 0.010$ \\
\hline
\end{tabular}

IF-depleted and control IF preparations were made as described in Methods. Experiments were conducted as described in Table IV. Uptakes represent the mean $\pm \mathrm{SD}$ of three experiments.
Although competition by free IF could explain the reduction in $\mathrm{IFB}_{12}$ uptake observed in these experiments, it was also possible that inhibition by other constituents of the IF preparation could account for these findings. To investigate this alternative, experiments were performed testing the ability of IF preparation specifically depleted of cobamide-binding proteins by passage through a vitamin $B_{12}-$ Sepharose column to inhibit $I_{F B}$ uptake. The results (Table $\mathrm{V}$ ) show that preincubation of brush borders with IF preparation passed through a vitamin $\mathrm{B}_{12}$-Sepharose column had no effect on brush border $\mathrm{IFB}_{12}$ uptake. IF preparation passed through a $\mathrm{B}_{12}$-free Sepharose column, on the other hand, inhibited brush border $\mathrm{IFB}_{12}$ uptake approximately as much as IF preparation not subjected to chromatography. These results are consistent with the notion that free IF, rather than another constituent of the IF preparation, is responsible for the reduction in $\mathrm{IFB}_{12}$ uptake that follows preincubation of ileal brush borders with the preparation.

The extent of inhibition of IFB $_{12}$ uptake was found to depend on the duration of preincubation of brush borders with free IF. Fig. 7 shows that inhibition of IFB $_{12}$ uptake by free IF develops moderately rapidly during the preincubation, reaching its fullest extent by about $20 \mathrm{~min}$. The rate at which inhibition appears is roughly comparable to the rate at which the $\mathrm{IFB}_{12}$ complex attaches to receptor in the absence of free IF (cf. Fig. 5a).

Although inhibition of $\mathrm{IFB}_{12}$ uptake was not observed when equal amounts of $\mathrm{IFB}_{12}$ complex and free IF were simultaneously added to brush borders, inhibition was observed under these conditions with larger

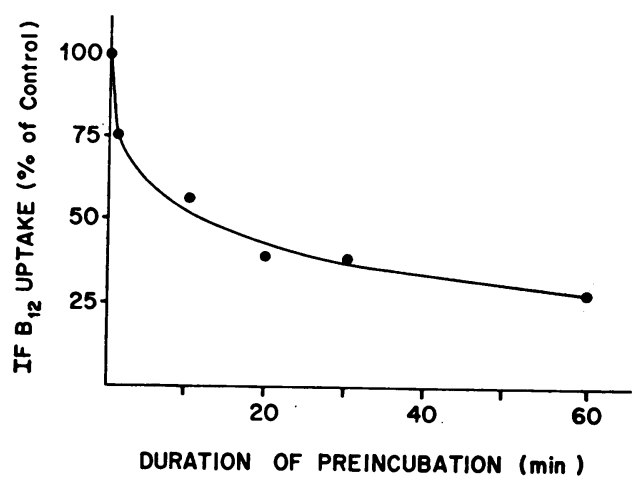

Figure 7 Effect of preincubation of brush borders with free IF on subsequent brush border uptake of radioactive $I_{F B}$. Reaction mixtures containing brush borders $(1 \mathrm{mg}$ tissue protein) in $5 \mathrm{ml} \mathrm{KRB}$ were incubated with $1.5 \mathrm{pmol}$ free IF at room temperature for the times indicated. In control tubes brush borders were incubated in KRB without free IF. $\left[{ }^{\infty} \mathrm{Co}\right] \mathrm{CN}-\mathrm{Cbl} \cdot \mathrm{IF}(1.5 \mathrm{pmol})$ was then added and the incubation was continued for an additional hour. Uptake of $\mathrm{IFB}_{12}$ by brush borders was then determined by centrifugation (see Methods). Uptakes are expressed as percent of control values. Error bars indicate $\pm 1 \mathrm{SD}$. 
amounts of free IF. Fig. 8 shows inhibition of $I_{1 F B}$ uptake as a function of the concentration of free IF. When brush borders were not preincubated with free $\mathrm{IF}$, slight but significant interference with $\mathrm{IFB}_{12}$ uptake was observed at free $\mathrm{IF} / \mathrm{IFB}_{12}$ ratios as low as 2 . The extent of interference increased with increasing concentrations of free IF. Preincubation of brush borders with free IF greatly augmented the interference with IFB $_{12}$ uptake at each concentration of free IF.

The results of experiments to determine the nature of the inhibition of $\mathrm{IFB}_{12}$ uptake by free $\mathrm{IF}$ are shown in Fig. 9. While uptake data obtained in the absence of free IF could be fitted well to a Michaelis-Menten plot by a nonlinear least squares method, the data obtained in the presence of free IF could not be so fitted within the limits of experimental error. This finding indicates that inhibition by free IF under these experimental conditions is neither competitive, noncompetitive, nor mixed, but instead displays an unconventional pattern. Perhaps the unusual nature of the inhibition may be explained by proposing that true equilibrium was not attained during the course of the incubation. In any event, that significant inhibition was effected by 2.3 $\mathrm{nM}$ IF indicates that the binding of free IF to the ileal receptor is tight.

\section{DISCUSSION}

Previous studies have shown that several cobalamins prevent binding of $\mathrm{CN}-\mathrm{Cbl}$ to IF (25-27), and are themselves absorbed by an IF-dependent mechanism (28-31). Derivatives with an altered corrin ring or benzimidazole moiety did not appear to inhibit binding of $\mathrm{CN}-\mathrm{Cbl}$ to IF (32), and appeared to be poorly absorbed by humans and experimental animals (33). These studies indicated in a qualitative way a relationship between $B_{12}$ structure, its binding to IF, and its subsequent absorption.

Quantitative data from the present investigation and from previous investigations reported by Hippe, Haber, and Olesen (34), Hippe and Oleson (35), and Allen and Mehlman (36) accord with the results of the more qualitative studies referred to above. In the present studies, the affinity of $\mathrm{CN}-\mathrm{Cbl}$ for IF was not significantly altered by substitution at the $-\mathrm{CN}$ position, suggesting that the ligand at this position is not involved in the binding process. The e-amido group on the corrin ring, however, appears to play a significant role in binding to IF, since removal of this single amide group to form $\mathrm{CN}-\mathrm{Cbl}(\mathrm{OH})^{\mathrm{e}}$ markedly reduces affinity. The base coordinated to the cobalt is apparently critical in the binding process. Replacement of the dimethylbenzimadole moiety of $\mathrm{CN}-\mathrm{Cbl}$ by adenine $[\mathrm{CN}-\mathrm{Cbl} \rightarrow$ (Ade)$\mathrm{CN}-\mathrm{Cba}$ ] greatly reduced affinity, while removal of base $[\mathrm{CN}-\mathrm{Cbl} \rightarrow(\mathrm{CN}, \mathrm{OH}) \mathrm{Cbi}]$ rendered the derivative incapable of competing with $\mathrm{CN}-\mathrm{Cbl}$ for binding

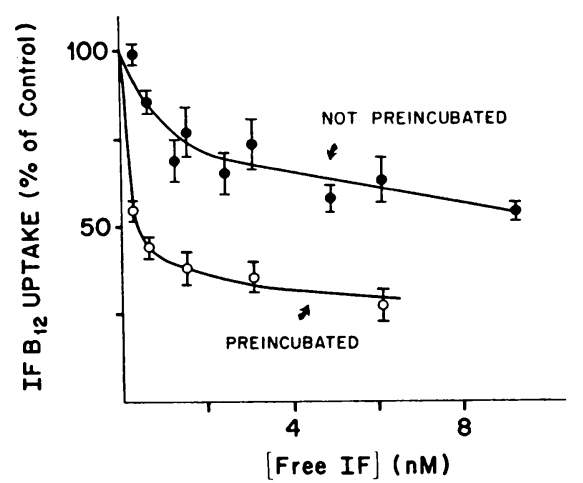

FIGURE 8 Inhibition of $\mathrm{IFB}_{12}$ uptake as a function of the concentration of free IF. Reaction mixtures contained brush borders (1 mg tissue protein), $\left[{ }^{57} \mathrm{Co}\right] \mathrm{CN}-\mathrm{Cbl} \cdot \mathrm{IF} \quad(1.5$ pmol), and free IF at the concentrations indicated. In one set of experiments $(-\bullet)$, all constituents were added at the same time. In the other set of experiments $(\mathrm{O}-\mathrm{O})$, brush borders in KRB were incubated with free IF for $1 \mathrm{~h}$ at $37^{\circ} \mathrm{C}$. $\left[{ }^{57} \mathrm{Co}\right] \mathrm{CN}-\mathrm{Cbl} \cdot \mathrm{IF}$ was then added and the incubation was continued for an additional hour. For each set of experiments, control tubes were incubated under precisely the same conditions except that no free IF was included in the reaction mixtures. Uptake of complex by brush borders was determined by the method of centrifugation (see Methods). Uptakes are expressed as percent of control values. Error bars indicate $\pm 1 \mathrm{SD}$.

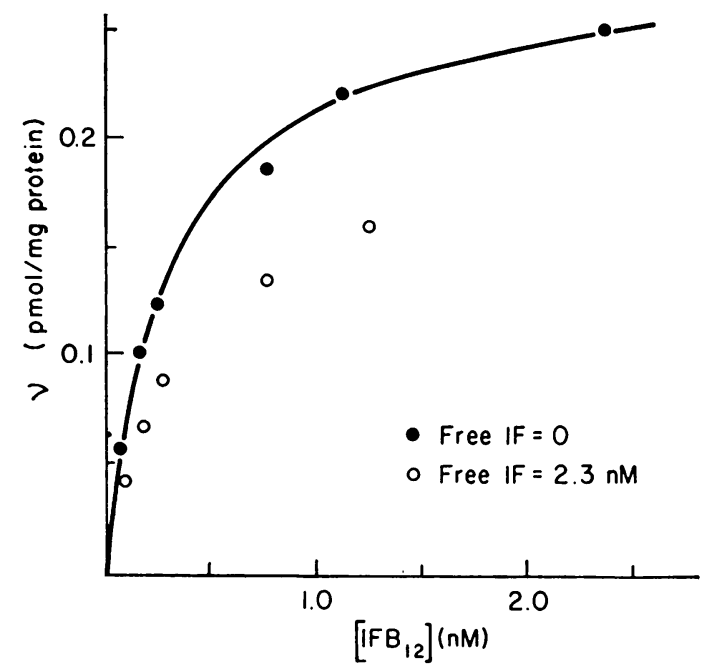

FIGURE 9 Kinetics of inhibition of the attachment of IFB $_{12}$ complex to brush border receptor by free IF. Reaction mixtures contained brush borders ( $1 \mathrm{mg}$ protein), $5 \mathrm{ml}$ $\mathrm{KRB}, \mathrm{IFB}_{12}$ complex at the concentrations shown, and, where indicated, $2.3 \mathrm{nM}$ free IF. There was no preliminary incubation. Reaction mixtures were incubated at $37^{\circ} \mathrm{C}$ for 1 h. Uptake of $\mathrm{IFB}_{12}$ complex by brush border receptor was then determined by the method of centrifugation (see Methods).

The curve drawn through the closed circles was calculated by a nonlinear least-squares fit of the data obtained in the absence of free IF to the Michaelis-Menten equation. The parameters obtained from this curve-fitting procedure were as follows: $K_{\boldsymbol{M}}=0.31 \mathrm{nM}, \nu_{\boldsymbol{M}}=0.28 \mathrm{pmol} / \mathrm{mg}$ protein.

Attachment of Cobamides to Ileal Receptor 
to IF. These results support the model of IF- $\mathrm{B}_{12}$ binding proposed by Gräsbeck ( 37 ), who suggested that the $\mathrm{B}_{12}$ molecule fits into a pit on the globular IF molecule with the nucleotide facing inward and the $-\mathrm{CN}$ side of the planar corrin ring facing outward.

The present studies also demonstrated the uptake of the complex between cobamide and human IF by the guinea pig ileal receptor. Previous workers have shown that human IF promotes uptake of vitamin $B_{12}$ by everted sacs (3) and homogenates (4) of guinea pig ileum. In our study, vitamin $\mathrm{B}_{12}$ bound to human IF was preferentially taken up by whole mucosal homogenates, brush borders, and microvillous membranes prepared from the distal but not the proximal half of guinea pig small bowel. Binding of $\mathrm{IFB}_{12}$ complex per milligram of tissue protein increased as the relative amount of microvillous membrane in the preparation increased. Similar dissociation constants were determined for the attachment of $\mathrm{IFB}_{12}$ complex to each of the mucosal preparations $(0.21 \mathrm{nM}, 0.30 \mathrm{nM}$, and 0.25 $\mathrm{nM}$ for whole mucosal homogenate, brush borders, and microvillous membranes, respectively). Although human IF enhanced attachment of vitamin $\mathrm{B}_{12}$, other proteins that bind vitamin $\mathrm{B}_{12}$ but that lack intrinsic factor, i.e., $\mathrm{R}$ binders (9) prepared from human gastric juice, saliva, and serum, were totally ineffective. Thus, as in the hamster (2), intestinal receptors specific for $\operatorname{IFB}_{12}$ complex are located on microvillous membranes of absorptive cells in the guinea pig ileum. The advantage of using microvillous membranes from guinea pigs rather than from hamsters is that human IF can be studied.

The rate constant for the dissociation of $\mathrm{IFB}_{12}$ from the receptor indicates a half-time for dissociation of about $35 \mathrm{~min}$. This value suggests that the lifetime of the complex is sufficiently long to permit the vitamin to be slowly transported into the mucosal cell. There is considerable evidence that transport of the vitamin across the intestine is a slow process (38).

Although the rate of dissociation is slow, the rate of attachment of $\mathrm{IFB}_{12}$ to receptor is rapid. Since this rate of attachment is proportional to the concentration of $\mathrm{IFB}_{12}$ in the incubation medium, a half-time for the attachment process would be difficult to interpret in physiological terms. A physiological interpretation is provided by a comparison of the second-order rate constant determined in our experiments with the maximum possible second-order rate constant; namely, the rate constant of a reaction in which velocity is limited by the rate of diffusion of the reactants. Such a comparison shows that about $1 \%$ of all encounters between IFB $_{12}$ and receptor are productive of attachment.

Controversy exists as to whether or not IF not complexed with vitamin $\mathrm{B}_{12}$ (free IF) is able to attach to the ileal receptor. Herbert ( 7$)$ concluded from experiments in which everted intestinal sacs were sequentially incubated first with free IF and then with IFB $_{12}$ complex that free IF was capable of attaching to the ileal receptor. On the other hand, attachment of free IF could not be demonstrated by Strauss and Wilson (8), who simultaneously incubated everted sacs with free IF and $I B_{12}$. From the results of the present study, it is apparent that under the usual experimental conditions, attachment of $\mathrm{IFB}_{12}$ takes considerable time to reach completion (Fig. $5 a$ ). It therefore seemed possible that the discrepant findings concerning uptake of free IF by intestinal tissue might be related to the time required for free IF to attach to the ileal receptor. The results described above indicate that when brush borders are preincubated with free $I F$, subsequent uptake of $\mathrm{IFB}_{12}$ is inhibited (Table IV), and that the extent of inhibition is related to the duration of preincubation (Fig. 7). The possibility that the reduction of $\mathrm{IFB}_{12}$ uptake is an effect of a nonspecific inhibitor in the IF preparation, rather than an effect of free IF, is unlikely (Table V).

It thus appears that free IF attaches to the ileal receptor. This attachment process, however, occurs more slowly than for $I_{F B}$. In addition to free IF, each of the analog.IF complexes tested was able to compete with $\mathrm{CN}-\mathrm{Cbl} \cdot \mathrm{IF}$ for the receptor. Since the affinities of the analog. IF complexes for the receptor varied by less than a factor of three, it appears that the nature of the cobamide bound to IF has little effect on the interaction between IF and its receptor.

\section{ACKNOWLEDGMENTS}

We are grateful to Dr. J. S. Trier for electron microscopy of microvillous membrane preparations, and to Dr. John Gennari for fitting the curve shown in Fig. 9.

This work was supported in part by grants AM-11867, AM-16589, AM-09115, and RR-05598 from the National Institutes of Health, U. S. Public Health Service, and a grant from The Medical Foundation, Inc. V. I. Mathan was supported by a fellowship from the Wellcome Trust.

\section{APPENDIX}

Measurement of the $K_{\mathrm{B}}$ for the inhibition of binding of $\left[{ }^{60} \mathrm{Co}\right] \mathrm{CN}-\mathrm{Cbl}$ to $I F$ by $B_{18}$ analogs. In a system consisting of a small molecular ligand and a macromolecule to which it binds, a second compound that binds to the macromolecule and thereby prevents the binding of the first ligand is called a competitive inhibitor. This situation can be represented by the equilibria :

$$
\begin{aligned}
& E+L \stackrel{K_{L}}{\rightleftharpoons} E L \\
& E+I \stackrel{K_{\boldsymbol{X}}}{\rightleftharpoons} E I
\end{aligned}
$$

The equation which relates the extent of saturation of the macromolecule with ligand to the concentrations of ligand and inhibitor is :

$$
Y=\frac{1}{1+\frac{1}{K_{L}[L]}+\frac{K_{X}[I]}{K_{L}[L]}}
$$


where $Y$ is the fractional saturation of the macromolecule, $K_{L}$ and $K_{x}$ are the association constants for ligand and inhibitor, respectively, and $[L]$ and $[I]$ the the concentrations of the unbound species.

Ordinarily, the concentrations of both ligand and inhibitor are large relative to the concentration of macromolecule, so the concentration of unbound species is approximately equal to its total concentration. Under such circumstances, the total concentration of ligand and inhibitor can be used with the above equation to determine binding constants. However, in the present experiments, the total concentration of ligand was always of the same order of magnitude as that of the macromolecule, and the total concentration of inhibitor was frequently so. Moreover, while the concentration of unbound ligand was known from the experimental data, the concentration of unbound inhibitor could not be measured directly. For experiments in which the inhibitor concentration was large compared to the concentration of macromolecule and ligand, so that $\left[I_{t}\right] \sim[I]$, the inhibition constant could be determined by plotting the data according to Scatchard (14); the slope of the line, which in the absence of inhibitor is equal to $-1 / K_{L}$, becomes equal to $-1 / K_{L}\left(1+K_{X}\left[I_{t}\right]\right)$ in the presence of inhibitor at a total concentration of $\left[I_{t}\right]$. However, when both ligand and inhibitor are present at concentrations of the same order of magnitude as the macromolecule, the Scatchard plot fails. An equation which permits the $K_{\mathfrak{i}}$ to be determined under these conditions was derived as follows. The equilibria are

$$
\begin{aligned}
{[E L] } & =K_{L}[E][L] \\
{[E I] } & =K_{X}[E][I] \\
& =K_{X}[E]\left(\left[I_{t}\right]-[E I]\right),
\end{aligned}
$$

where $K_{L}, K_{x},[L],[I]$, and $\left[I_{t}\right]$ are defined as before, ( $K_{L}$ and $K_{X}$ being expressed in reciprocal concentration) and $[E],[E L]$, and $[E I]$ are the concentrations of free macromolecule, macromolecule-ligand complex, and macromolecule-inhibitor complex, respectively. Solving Eq. 3,

$$
[E I]=\frac{K_{X}[E]\left[I_{t}\right]}{1+K_{X}[E]}
$$

Adding $[E]$ to both sides of Eq. 4 and rearranging,

$$
[E I]+[E]=\frac{[E]\left(1+K_{X}[E]+K_{X}\left[I_{t}\right]\right)}{1+K_{X}[E]}
$$

Expressing the concentrations of the various species of macromolecule in terms of fractional saturation, since

$$
[E]+[E L]+[E I]=\left[E_{t}\right]
$$

where $\left[E_{t}\right]$ is the total concentration of macromolecule, then by definition

and

$$
Y=\frac{[E L]}{\left[E_{t}\right]}
$$

$$
1-Y=\frac{[E]+[E I]}{\left[E_{t}\right]}
$$

Dividing Eq. 7 by Eq. 8,

$$
\begin{aligned}
\frac{[E L]}{[E]+[E I]} & =\frac{Y}{1-Y} \\
& =\frac{K_{L}[L]\left(1+K_{X}[E]\right)}{1+K_{X}[E]+K_{X}\left[I_{t}\right]}
\end{aligned}
$$

where Eq. 10 is obtained from the left-hand side of Eq. 9 by appropriate substitution from Eq. 1 and 5 .

Solving for $[E]$ between Eq. 1 and 7 yields the expression

$$
[E]=\frac{Y\left[E_{t}\right]}{K_{L}[L]}
$$

Substituting into Eq. 10,

$$
\frac{Y}{1-Y}=\frac{K_{L}\left[L j+K_{X} Y\left[E_{t}\right]\right.}{1+\frac{K_{X} Y\left[E_{t}\right]}{K_{L}[L]}+K_{X}\left[I_{t}\right]}
$$

In this expression, all values except $K_{\boldsymbol{X}}$ can be directly obtained from the experimental data. When the reciprocal of this equation is taken and both sides are multiplied by $K_{L}[L]$, then

$$
\begin{aligned}
\frac{1-Y}{Y} K_{L}[L] & =\frac{K_{L}[L]+K_{X} Y\left[E_{t}\right]+K_{L} K_{X}[L]\left[I_{t}\right]}{K_{L}[L]+K_{X} Y\left[E_{t}\right]} \\
& =1+\frac{K_{L} K_{X}[L]\left[I_{t}\right]}{K_{L}[L]+K_{X} Y\left[E_{t}\right]} \\
& =1+\frac{K_{X}\left[I_{t}\right]}{1+Y \frac{K_{X}\left[E_{t}\right]}{K_{L}[L]}}
\end{aligned}
$$

Rearranging,

$$
\begin{aligned}
\frac{1-Y}{Y} K_{L}[L]-1 & =\frac{(1-Y) K_{L}[L]-Y}{Y} \\
& =\frac{K_{X} I_{t}}{1+Y \frac{K_{X}\left[E_{t}\right]}{K_{L}[L]}}
\end{aligned}
$$

On taking the reciprocal and rearranging again,

$$
\frac{\left[I_{t}\right]}{\frac{K_{L}[L]}{Y}-K_{L}[L]-1}=\frac{Y}{K_{L}[L]}\left[E_{t}\right]+\frac{1}{K_{X}}
$$

When the left-hand side of this equation is plotted against $Y / K_{L}[L]$, a line is obtained whose $y$-intercept is equal to $1 / K_{x}$, that is, to the dissociation constant $\left(K_{i}\right)$ for the inhibitor.

This equation contains two internal checks on the appropriateness of the model to the physical situation. First, plotting the data according to Eq. 15 should produce a straight line. Second, the slope of the line should be $\left[E_{t}\right]$, a quantity whose value is known from direct measurement.

\section{REFERENCES}

1. Castle, W. B. 1968. Gastric intrinsic factor and vitamin $\mathrm{B}_{12}$ absorption. Handb. Physiol., Section 6. 3: 1529-1552.

2. Donaldson, R. M., Jr., I. L. Mackenzie, and J. S. Trier. 1967. Intrinsic factor-mediated attachment of vitamin $\mathrm{B}_{12}$ to brush borders and microvillous membranes of hamster intestine. J. Clin. Invest. 46: 1215-1228.

3. Wilson, T. H., and E. W. Strauss. 1959. Some species differences in the intrinsic factor stimulation of $\mathrm{B}_{12}$ uptake by small intestine in vitro. Am. J. Physiol. 197: 926-928.

4. Sullivan, L. W., V. Herbert, and W. B. Castle. 1963. In vitro assay for human intrinsic factor. J. Clin. Invest. 42: $1443-1458$

5. Herbert, V., and W. B. Castle. 1961. Divalent cations and $\mathrm{pH}$ dependence of rat intrinsic factor action in

Attachment of Cobamides to Ileal Receptor 
everted sacs and mucosal homogenates of rat small intestine. J. Clin. Invest. 40: 1978-1983.

6. Mackenzie, I. L., and R. M. Donaldson, Jr. 1972. Effect of divalent cations and $\mathrm{pH}$ on intrinsic factormediated attachment of vitamin $\mathrm{B}_{12}$ to intestinal microvillous membranes. J. Clin. Invest. 51: 2465-2471.

7. Herbert, V. 1959. Mechanism of intrinsic factor action in everted sacs of rat small intestine. J. Clin. Invest. 38: $102-109$

8. Strauss, E. W., and T. H. Wilson. 1960. Factors controlling $\mathrm{B}_{12}$ uptake by intestinal sacs in vitro. Am. J. Physiol. 198: 103-107.

9. Gräsbeck, R., K. Simons, and I. Sinkkowen. 1966. Isolation of intrinsic factor and its probable degradation product, as their vitamin $B_{12}$ complexes, from human gastric juice. Biochim. Biophys. Acta. 127: 47-58.

10. Donaldson, R. M., Jr., and J. H. Katz. 1963. Exchange between free and gastric juice-bound cyanocobalamin. J. Clin. Invest. 42: 534-545.

11. Gottlieb, C., K. S. Lau, L. R. Wasserman, and V. Herbert. 1965. Rapid charcoal assay for intrinsic factor (IF), gastric juice unsaturated $\mathrm{B}_{12}$ binding capacity, antibody to $I F$, and serum unsaturated $B_{12}$ binding capacity. Blood J. Hematol. 25 : 875-884.

12. Retief, F. P., C. W. Gottlieb, S. Kochwa, P. W. Pratt, and V. Herbert. 1967. Separation of vitamin $\mathrm{B}_{12}$-binding proteins of serum, gastric juice and saliva by rapid DEAE cellulose chromatography. Blood J. Hematol. 29: $501-516$

13. Johnson, A. W., L. Mervyn, N. Shaw, and E. L. Smith. 1963. A partial synthesis of the vitamin $B_{12}$ coenzyme and some of its analogues. J. Chem. Soc. 1963: 4146-4156.

14. Babior, B. M. 1970. Mechanism of action of ethanolamine deaminase. VI. Ethylene glycol, a quasi-substrate for ethanolamine deaminase. J. Biol. Chem. 245: 17551766.

15. Kaplan, B. H., and E. R. Stadtman. 1968. Ethanolamine deaminase, a cobamide coenzyme-dependent enzyme. II. Physical and chemical properties and interaction with cobamides and ethanolamine. J. Biol. Chem. 243: 1794-1803.

16. Barker, H. A. 1962. $B_{12}$ coenzymes and processes for preparing the same. U. S. Patent 3,037,016 May 29.

17. Bernhauer, K., F. Wagner, H. Beisbarth, P. Rietz, and H. Vogelmann. 1966. Zur Chemie und Biochemie der Corrinoide. XXVI. Darstellung und Charakterisierung von Corrinoidcarbonsäuren. Biochem. Z. 344: 289-309.

18. Weissbach, H., J. N. Ladd, B. E. Volcani, R. D. Smyth, and H. A. Barker. 1960. Structure of the adenylcobamide coenzyme: degradation by cyanide, acid, and light. J. Biol. Chem. 235: 1462-1473.

19. Pratt, J. M. 1972. Inorganic chemistry of vitamin $B_{12}$. Academic Press, Inc., New York. 53.

20. Eichholz, A., and R. K. Crane. 1965. Studies on the organization of the brush border in intestinal epithelial cells. I. Tris disruption of isolated hamster brush borders and density gradient separation of fractions. $J$. Cell. Biol. 26: 687-691

21. Scatchard, G. 1949. The attractions of proteins for small molecules and ions. Ann. N. Y. Acad. Sci. 51: 660-672.

22. Allen, R. H., and P. W. Majerus. 1972. Isolation of vitamin $\mathrm{B}_{12}$-binding proteins using affinity chromatography. I. Preparation and properties of vitamin $\mathrm{B}_{12-}$ Sepharose. J. Biol. Chem. 247: 7695-7701.
23. Lowry, O. H., N. J. Rosebrough, A. L. Farr, and R. J. Randall. 1951. Protein measurement with the Folin phenol reagent. J. Biol. Chem. 193: 265-275.

24. McGuigan, J. E. 1967. Measurement of the affinity of human gastric juice intrinsic factor for cyanocobalamin. J. Lab. Clin. Med. 70: 666-672.

25. Bunge, M. B., and R. F. Schilling. 1957. Intrinsic factor studies. VI. Competition for vitamin $\mathrm{B}_{12}$ binding sites offered by analogs of the vitamin. Proc. Soc. Exp. Biol. Med. 96: 587-592.

26. Gregory, M. E., and E. S. Holdsworth. 1960. The binding of cyanocobalamin and its naturally occurring analogues by certain body fluids and tissue extracts. Biochim. Biophys. Acta. 42: 462-469.

27. Gottlieb, C. W., F. P. Retief, and V. Herbert. 1967. Blockade of vitamin $\mathrm{B}_{12}$-binding sites in gastric juice, serum, and saliva by analogues and derivatives of vitamin $\mathrm{B}_{12}$ and by antibody to intrinsic factor. Biochim. Biophys. Acta. 141: 560-572.

28. Rosenblum, C., D. T. Woodbury, J. P. Gilbert, K. Okuda, and B. F. Chow. 1955. Comparative absorption of vitamin $\mathrm{B}_{12}$ analogues by normal humans. I. Chlorocobalamin versus cyanocobalamin. Proc. Soc. Exp. Biol. Med. 89: 63-66.

29. Rosenblum, C., R. S. Yamamato, R. Wood, D. T. Woodbury, K. Okuda, and B. F. Chow. 1956. Comparative absorption of vitamin $\mathrm{B}_{12}$ analogues by normal humans. II. Chloro-, sulphate-, nitro-, and thiocyanatovs cyanocobalamin. Proc. Soc. Exp. Biol. Med. 91: 364-367.

30. Latner, A. L., and L. Raine. 1957. Effect of analogues on the uptake of vitamin $\mathrm{B}_{12}$ by the intact rat. Nature (Lond.). 180: 1197-1198.

31. Okuda, K., L. Yashima, and M. Takamatsu. 1969. Intestinal absorption of cobamide coenzyme in relation to structural integrity and intrinsic factor. J. Lab. Clin. Med. 74: 218-228.

32. Bunge, M. B., L. L. Schloesser, and R. F. Schilling. 1956. Intrinsic factor studies. IV. Selective absorption and binding of cyanocobalamin by gastric juice in the presence of excess of pseudovitamin $\mathrm{B}_{12}$ or 5,6-dimethylbenzimidazole. J. Lab. Clin. Med. 48: 735-744.

33. Toporek, M. 1960. The relation of binding power to intrinsic factor activity. Effect of pseudovitamin $\mathrm{B}_{12}$ on absorption of vitamin $\mathrm{B}_{12}$. Am. J. Clin. Nutr. 8: 297300 .

34. Hippe, E., E. Haber, and H. Olesen. 1971. Nature of vitamin $B_{12}$ binding. II. Steric orientation of vitamin $\mathrm{B}_{12}$ on binding and number of combining sites of human intrinsic factor and the transcobalamins. Biochim. Biophys. Acta. $243:$ 75-82.

35. Hippe, E., and H. Olesen. 1971. Nature of vitamin $B_{12}$ binding. III. Thermodynamics of binding to human intrinsic factor and transcobalamins. Biochim. Biophys. Acta. 243: 83-89.

36. Allen, R. H., and C. S. Mehlman. 1973. Isolation of gastric vitamin $\mathrm{B}_{12}$-binding proteins using affinity chromatography. I. Purification and properties of human intrinsic factor. J. Biol. Chem. 248: 3660-3669.

37. Gräsbeck, R. 1969. Intrinsic factor and other vitamin $\mathrm{B}_{12}$ transport proteins. Prog. Hematol. 6: 233-260.

38. Doscherholmen, A., and P. S. Hagen. 1959. Delay in absorption of radiolabeled cyanocobalamin in the intestinal wall in the presence of intrinsic factor. J. Lab. Clin. Med. 54: 434-439. 